\title{
Research on the Influence of Density and Fertilization Concerning the Sunflower (Helianthus annuus) Hibrids Quality on the Cambic Chernozem from Fundulea
}

\author{
Florentina EREMIA ${ }^{1}$, Costică CIONTU ${ }^{1}$ \\ ${ }^{1}$ University of Agronomic Science and Veterinary Medicine, 59 Marasti, sector 1, 011464, Bucharest, \\ Romania \\ * corresponding author: eremiaflorentina89@yahoo.com
}

Bulletin USAMV series Agriculture 72(1)/2015

Print ISSN 1843-5246; Electronic ISSN 1843-5386

DOI 10.15835/buasvmcn-agr: 11151

\begin{abstract}
Research was done in an experimental field of NARDI Fundulea, not irrigated variant, the main purpose being the influence of density and fertilization on the production quality of three sunflower hybrids (a1 - Performer; a2 - KWS Barolo R0; a3 - PR64A89). Concerning the plant density, they were used two variants, respectively c1 of 50,000 plants/ha, and c2 of 60,000 plants/ha.

Other significant factors were the climate and soil conditions. In the area, the experimental conditions are characterized by the transition from steppe to forest steppe that allows especially the formation of cambic chernozem category soil. The quality data processing was performed following the analysis in the laboratory of sunflower seeds, yielded as samples of $750 \mathrm{~g}$. After removing the impurities they have been determined 1000GrainWeight, hl mass, and the seeds oil content in the conditions of 2012 year climate.
\end{abstract}

Keywords: chernozem, Helianthus annuus, hybrids, hl mass, 1000GrainWeight.

\section{INTRODUCTION}

Experimental field is in the East of Romanian Plain area, on the Mostistea river side, along the border between Vlasiei Plain and South Baragan Plain. As geographical position is approximately 44 ${ }^{\circ} 30^{\prime}$ North latitude and $24^{\circ} 10^{\prime}$ East longitude, on the territory of the Fundulea town, Călăraşi County, $34 \mathrm{~km}$ East of Bucharest. Fundulea groundwater depth is about $14 \mathrm{~m}$ and an average elevation of $56 \mathrm{~m}$. The area of vegetation is at the crossing between the steppe and forest steppe. The climate is predominantly character. The frequency of dry years is over $40 \%$. They are common drought periods, of 10-14 days, in May-June, and of about
30 days or longer at the beginning of spring and especially at the beginning of fall. The duration of sunshine is of 2,165 hours multiannual average (Partal et al. 2008).

The research objectives aimed at optimizing culture technology in order to achieve maximum and constant sunflower yield, in the soil and climate conditions of southern Romania, also following the economic efficiency and environmental protection.

Due to its high oil content in seeds commonly exceeding $48-50 \%$ of the dry substance, sunflower is a typical oleaginous plant, whose economic value derives $80 \%$ of its edible oil (Bîlteanu 2003). 


\section{AIMS AND OBJECTIVES}

The research objectives aimed at optimizing culture technology in order to achieve maximum and constant sunflower yield, in the soil and climate conditions of southern Romania, also following the economic efficiency and environmental protection.

Due to its high oil content in seeds commonly exceeding $48-50 \%$ of the dry substance, sunflower is a typical oleaginous plant, whose economic value derives $80 \%$ of its edible oil .

\section{MATERIALS AND METHODS}

Research were performed in the experimental field of Systems of Sustainable Agriculture and Crops Fertilization (SSA-CF) not irrigated version, from NARDI Fundulea, pursuing the influence of density and fertilization on the harvest quality of three sunflower hybrids (a1 - Performer; a2 KWS Barolo R0; a3 - PR64A89).

Concerning the plant density they were used two variants, c1 of 50,000 plants/ha, and c2 of 60,000 plants/ha.

An important influence factor was the soil. Experimental conditions in the area are characterized by the transition from steppe to forest steppe that mostly allows the formation of cambic chernozem soil category. Humidity higher than in the steppe led to a proliferation of the clay formation. So, a large part of the clay content from the A level migrated towards the limit between levels $\mathrm{A}$ and $\mathrm{B}$.

Humus content is higher in the first $15 \mathrm{~cm}$ due to the former beds of leaves and gradually decreases towards depth (Partal et al. 2008).

The experimental diagram is three factorial type, $3 \times 3 \times 2$, ordered in three repetitions by the method of subdivided parcels. The experimental results were statistical processed using the variance analysis method (Gologan et al. 1981).

The experiment was located on uniform land in terms of fertility and landscape, on a chernozem soil, specific for the experimental area. The previous crop was wheat in all experimentation years.
The total experimental area was of $11,760 \mathrm{~m}^{2}$. The total surface for the experimental plot was $168 \mathrm{~m}^{2}$, and harvested area of $112 \mathrm{~m}^{2}$.

In order to organize the experiment it was used biologic material consisting of 3 sunflower hybrids. Plants cultivation was performed in optimum technological conditions, specific to the cultivation area, the studied genotypes comprising three hybrids: Performer (control - semi-late hybrid), Barolo RO (semi-late hybrid), and PR64A89 (semi-late hybrid).

\section{RESULTS AND DISCUSSION}

The highest HM and 1000GrainWeight values were registered at the variant fertilized with manure (20 t/ha) and a density of 50,000 plants/ ha.

The most favorable values were obtained from the hybrids PR64A89 and Performer, where $\mathrm{HM}$ was of $38 \mathrm{~kg} / 100 \mathrm{l}$, respectively of $37 \mathrm{~kg} / 100 \mathrm{l}$, 1000 GrainWeight of $54.7 \mathrm{~g}$, respectively of $55.5 \mathrm{~g}$.

\section{CONCLUSION}

From the analysis of these data, we can conclude that, in terms of a year with uneven distribution of rainfall in time and space, a variant yielded the best values of quality indicators is that fertilized with manure ( $20 \mathrm{t} / \mathrm{ha}$ ) where it was used the hybrid PR64A89.

\section{REFERENCES}

1. Bîlteanu Gh (2003). Phytotechnics. Ceres Publishing House, Bucharest.

2. Gologan I, Dornescu A ( 1981). Plant Breeding Course. Agronomy Institute Ion Ionescu de la Brad, Iasi.

3. Hera C, Sin Gh, Toncea I (1989). Sunflower crop. Ceres Publishing House, Bucharest.

4. Ion V, Hălmăjan HV (2001). Sunflower harvesting, storing and preserving the harvest. Journal of Cereals and technical crops 8:1-5.

5. Partal E, Zaharia GV (2008). Results on the effects of fertilization on the main field crops. Anals of NARDI Fundulea LXXIV:111-118. 